\title{
The Regulation of $\beta$-Glucanase Synthesis in Fungi and Yeast
}

\author{
By FRANCISCO DEL REY, ISABEL GARCIAA-ACHA AND \\ CÉSAR NOMBELA \\ Department of Microbiology, Faculty of Sciences and Institute of Biochemical \\ Microbiology, C.S.I.C., University of Salamanca, Spain
}

(Received 10 April 1978; revised 6 July 1978)

Glucose repressed the synthesis of 1,3- $\beta$-glucanase in Neurospora crassa. The production of enzyme during growth in glucose-supplemented medium was negligible, but if deprived of carbon source the fungus actively synthesized high levels of enzyme when growth ceased. Similar results were obtained for 1,6- $\beta$-glucanase but less enzyme was produced. A different pattern of production of these enzymes was found in Trichoderma viride and Saccharomyces cerevisiae. The enzymes were produced in glucose-supplemented medium with increasing specific activity during growth. Resting cells deprived of glucose either failed to produce $\beta$-glucanases or produced them in smaller quantities.

\section{INTRODUCTION}

1,3- $\beta$-Glucanase (EC 3.2.1.6) and 1,6- $\beta$-glucanase (EC 3.2.1.75) are fungal enzymes which probably have a number of roles in the cells producing them. A single species may produce several with different properties and modes of action. Catabolite repression regulates the production of some fungal glucanases (Santos et al., 1977). The 1,3- $\beta$-glucanase system of Penicillium italicum, which has been studied in detail, consists of three enzymes with different modes of action; two of them are produced at a low rate during the period of growth and attain higher levels in low-glucose medium, whereas the third appears only in the latter conditions (Santos et al., 1978a). It has been shown that the glucose effect is due to control at a pretranslational level (Santos et al., 1978a).

The present study was undertaken to test the validity of this model of carbon source regulation of $1,3-\beta$-glucanase production in other species. We found that in Neurospora crassa glucose regulates $1,3-\beta$-glucanase production in a similar manner to that of $P$. italicum. In contrast, growth of Trichoderma viride and Saccharomyces cerevisiae in the presence of glucose was accompanied by an increase in the specific activity of $1,3-\beta$ glucanase and enzyme production ceased in the stationary phase.

\section{METHODS}

Chemicals. Laminarin was purchased from Koch-Light. Pustulan was prepared from Umbilicaria pustulata (Lindberg \& McPherson, 1954). Glucose oxidase and peroxidase were from Sigma. All other reagents were of analytical grade from commercial sources.

Organisms, growth conditions and preparation of extracts. The following strains were used for this study: Neurospora crassa STA4 obtained from the Fungal Genetics Stock Center (Arcata, California 95521, U.S.A.); Trichoderma viride CECT 2423 obtained from the Spanish Type Culture Collection; and Saccharomyces

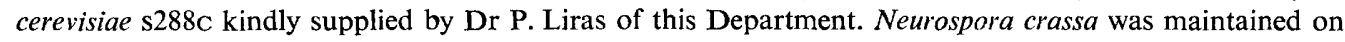
slants of Vogel medium (Vogel, 1956) plus $2 \%(\mathrm{w} / \mathrm{v})$ agar. Conidia were harvested by adding sterile distilled water, the conidial suspension was filtered through glass wool and the number of conidia was counted in a phase-contrast microscope using a haemocytometer (Thoma, E. Hartnack, Germany). Liquid cultures were grown by inoculating conidia (to a concentration of $2 \cdot 5 \times 10^{6} \mathrm{ml}^{-1}$ ) into 1 litre flasks containing $240 \mathrm{ml}$ 
Vogel medium and shaking the flasks $\left(240 \mathrm{rev} \cdot \mathrm{min}^{-1}\right)$ at $28^{\circ} \mathrm{C}$ in an orbital incubator (Gallenkamp). At intervals during the incubation period $3 \mathrm{ml}$ samples were withdrawn and assayed. Slants of GAE medium (García-Acha \& Villanueva, 1963) were used to maintain $T$. viride and liquid cultures were grown in a medium containing $110 \mathrm{~mm}$-glucose, $0.2 \%$ (w/v) asparagine, $0.2 \%(\mathrm{w} / \mathrm{v}) \mathrm{NaNO}_{3}, 0.075 \%(\mathrm{w} / \mathrm{v}) \mathrm{K}_{2} \mathrm{HPO}_{4}$, $0.05 \%(\mathrm{w} / \mathrm{v}) \mathrm{MgSO}_{4} .7 \mathrm{H}_{2} \mathrm{O}, 0.05 \%(\mathrm{w} / \mathrm{v}) \mathrm{KCl}$ and $0.0015 \%(\mathrm{w} / \mathrm{v}) \mathrm{FeSO}_{4} . \mathrm{H}_{2} \mathrm{O}$ (modified Czapek medium). Saccharomyces cerevisiae was maintained on slants of YED medium [2\%(w/v) glucose and $1 \%(\mathrm{w} / \mathrm{v})$ yeast extract plus $2 \%$ agar] and for liquid cultures either unbuffered minimal medium $[2 \%(\mathrm{w} / \mathrm{v})$ glucose and $0.7 \%$ (w/v) Difco Yeast Nitrogen Base] or the same medium buffered with 50 mm-phosphate buffer $\mathrm{pH} 7.0$ was used. The conditions for growing $T$. viride and $S$. cerevisiae were as described for N. crassa.

Two-step cultures were used to study the effect of glucose concentration on the production of $1,3-\beta-$ glucanase and 1,6- $\beta$-glucanase. Actively growing cells in a 1 litre flask were divided into two portions. Mycelium was collected by filtration through Whatman no. 2 filter paper and yeast cells by low-speed centrifugation. The cells were washed with $100 \mathrm{ml} 50 \mathrm{~mm}$-acetate buffer pH 5.2 and then with $100 \mathrm{ml}$ of medium similar to that used for growth (glucose concentration $5 \mathrm{~mm}$ ). The final suspensions were transferred to two $500 \mathrm{ml}$ flasks with similar medium but with glucose at $170 \mathrm{~mm}$ in one flask and $5 \mathrm{~mm}$ in the other. The flasks were shaken at $28^{\circ} \mathrm{C}$ and samples were taken at intervals for the determination of dry weight, glucose concentration and $\beta$-glucanases.

Ail operations for harvesting mycelia or yeast cells and preparing extracts were done in a cool room between 0 and $4^{\circ} \mathrm{C}$. Cells were harvested by filtration through Whatman no. 2 filter paper (mycelium) or by low-speed centrifugation (yeast cells), washed three times with $50 \mathrm{ml} 50 \mathrm{~mm}$-acetate buffer and finally suspended in this buffer $[0.5 \mathrm{~g}$ (wet wt) cells in $5 \mathrm{ml}$ buffer]. Ballotini beads (about $5 \mathrm{~g}$ ) were added to the suspension and cell-free extracts were prepared by mechanical breakage in a Braun homogenizer as described by Santos et al. (1977).

Growth determination. Growth of $N$. crassa and $T$. viride was measured by determining the dry weight of cells in samples filtered through Whatman no. 2 filter paper and dried in an oven at $80^{\circ} \mathrm{C}$ to constant weight. Growth of $S$. cerevisiae was monitored by measuring absorbance at $600 \mathrm{~nm}$.

Enzyme assays. The assays of 1,3- $\beta$-glucanase and 1,6- $\beta$-glucanase were based on release of reducing sugar groups from laminarin and pustulan, respectively. The enzymes were assayed in cell-free extracts and in the culture fluid by the procedure previously described (Santos et al., 1977). Samples from the culture fluid and extracts of $S$. cerevisiae (with a high content in reducing sugar groups) were dialysed before assay against $50 \mathrm{~mm}$-acetate buffer pH 5.2 for $12 \mathrm{~h}$. The unit of activity was defined as the amount of enzyme which catalysed the release of reducing sugar groups equivalent to $1 \mathrm{nmol}$ glucose $\mathrm{min}^{-1}$. Glucose in the culture medium was determined with glucose oxidase coupled to peroxidase, and protein was measured by the method of Lowry et al. (1951) using bovine albumin as standard. Specific activity was defined as units (mg protein) ${ }^{-1}$

\section{RESULTS}

\section{Glucose repression of $\beta$-glucanases}

The production of 1,3- $\beta$-glucanase and 1,6- $\beta$-glucanase by $N$. crassa grown in defined medium is shown in Fig. 1. During exponential growth, none of these enzymes were detected in cell-free extracts and only small amounts were found in the culture fluid. After glucose exhaustion, the culture entered the stationary phase of growth and the production of $\beta$-glucanases commenced. The specific activity of $1,3-\beta$-glucanase in cell-free extracts started to increase linearly and attained high values after $25 \mathrm{~h}$. The enzyme was also secreted into the culture medium. Production of 1,6- $\beta$-glucanase took place, but to a lesser extent. When actively growing cells were transferred to high-glucose medium (Fig. 2), which supported further growth, the specific activity of $1,3-\beta$-glucanase in extracts and the amount of enzyme in the culture fluid remained low; only when glucose was depleted due to cell growth was an increase detected. Transfer of actively growing cells to low-glucose medium $(5 \mathrm{~mm})$ resulted in increased production of intracellular and extracellular enzyme, and cell growth ceased (Fig. 2). 


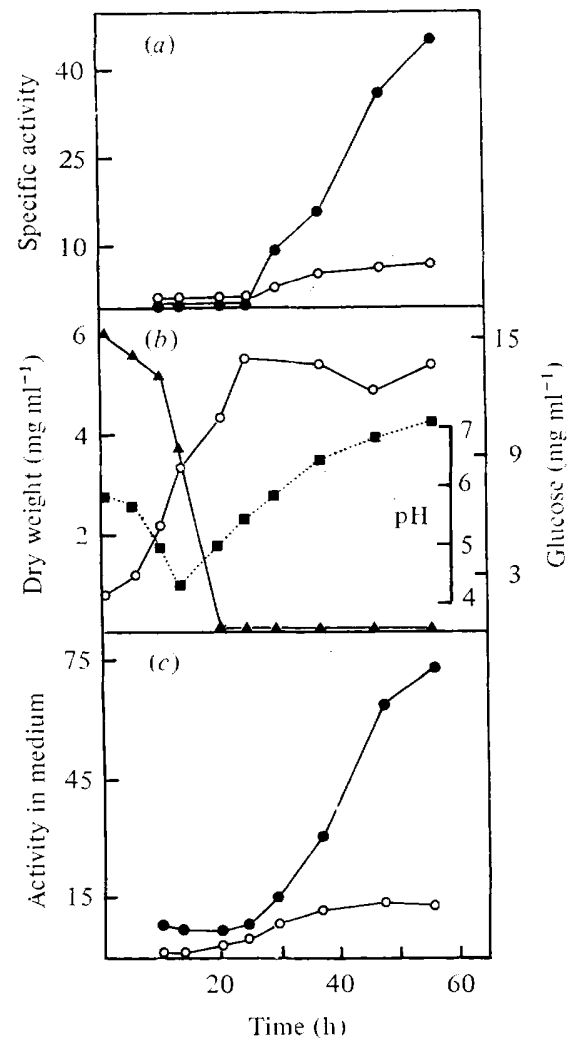

Fig. 1

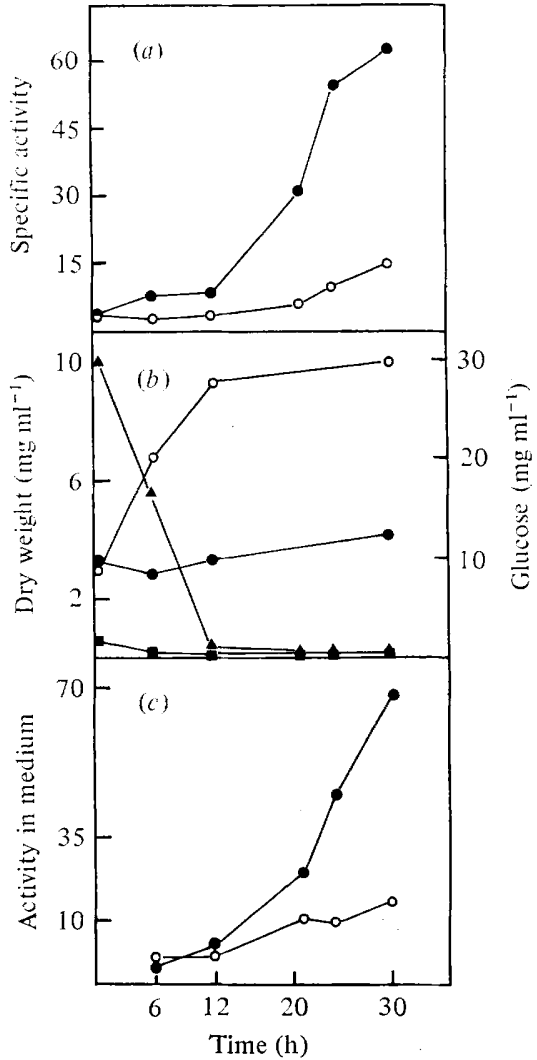

Fig. 2

Fig. 1. Production of 1,3- $\beta$-glucanase and 1,6- $\beta$-glucanase by Neurospora crassa grown in Vogel medium. (a) Specific activity [units (mg protein) $)^{-1}$ ] of 1,3- $\beta$-glucanase (O) and 1,6- $\beta$-glucanase $(O)$ in cell-free extracts. $(b)$ Dry weight of cells $(\bigcirc)$, glucose concentration $(\boldsymbol{\Delta})$ and $\mathrm{pH}(\boldsymbol{\square})$. (c) Activity in culture medium (units $\mathrm{ml}^{-1}$ ) of $1,3-\beta$-glucanase $(\mathbf{O})$ and $1,6-\beta$-glucanase $(O)$.

Fig. 2. Effect of glucose on the production of 1,3- $\beta$-glucanase by Neurospora crassa. Actively growing cells were transferred to media containing glucose at $5 \mathrm{~mm}(O)$ or $170 \mathrm{~mm}(\bigcirc)$, as described in Methods. (a) Specific activity [units (mg protein) ${ }^{-1}$ ] in cell-free extracts. (b) Glucose concentration $(\boldsymbol{A})$ and dry weight of cells $(O)$ in the high-glucose medium, and glucose concentration $(\square)$ and dry weight of cells $(\bullet)$ in the low-glucose medium. (c) Enzyme activity in culture medium (units $\mathrm{ml}^{-1}$ ).

\section{Glucose-insensitive synthesis of $\beta$-glucanases}

A different pattern of results was obtained when similar experiments were performed with another filamentous fungus, $T$. viride. Growth in defined medium was accompanied by a continuous increase in the specific activity of $1,3-\beta$-glucanase in extracts and in the activity of enzyme in the culture fluid (Fig. 3). Similar results were obtained for 1,6- $\beta$-glucanase although this enzyme was mostly extracellular since only small amounts of it remained cell-bound. When actively growing mycelium was transferred to medium containing 170 mu-glucose (Fig. 4), the cells grew and synthesized 1,3- $\beta$-glucanase since there was a significant increase in specific activity and in the amount of secreted enzyme. In low-glucose medium, no growth took place and production of $1,3-\beta$-glucanase was greatly reduced. It is clear, from these results, that synthesis of $1,3-\beta$-glucanase in $T$. viride accompanies growth.

Growth of S. cerevisiae in unbuffered medium (Fig. 5) led to a very low $\mathrm{pH}$ value and the specific activity of $\beta$-glucanases decreased thereafter. This suggested that low $\mathrm{pH}$ was probably responsible for inactivation of the enzymes since they have been described as being periplasmic (Cortat et al., 1972). This interpretation was confirmed when the yeast was 


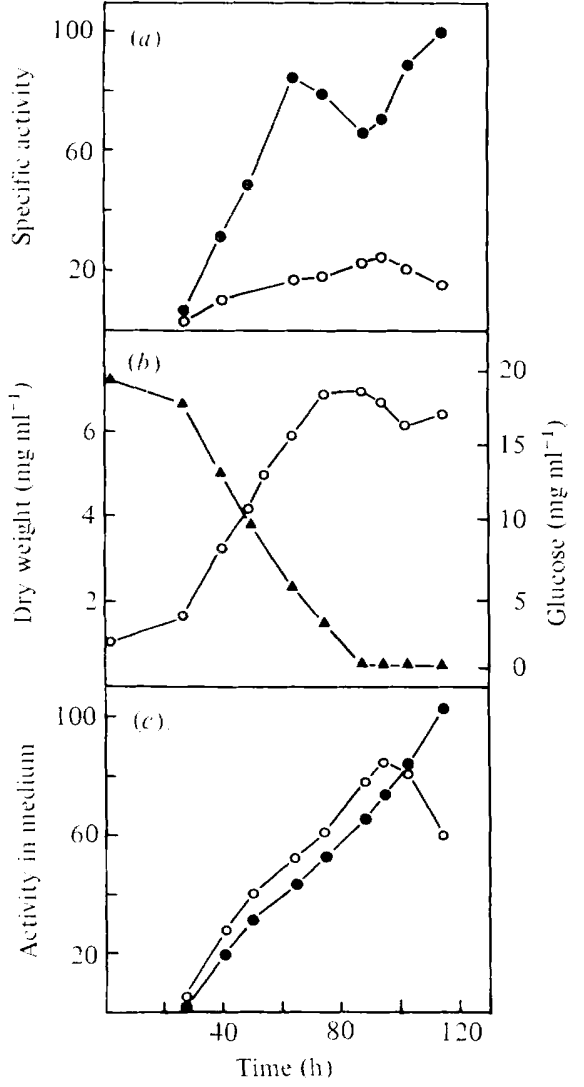

Fig. 3

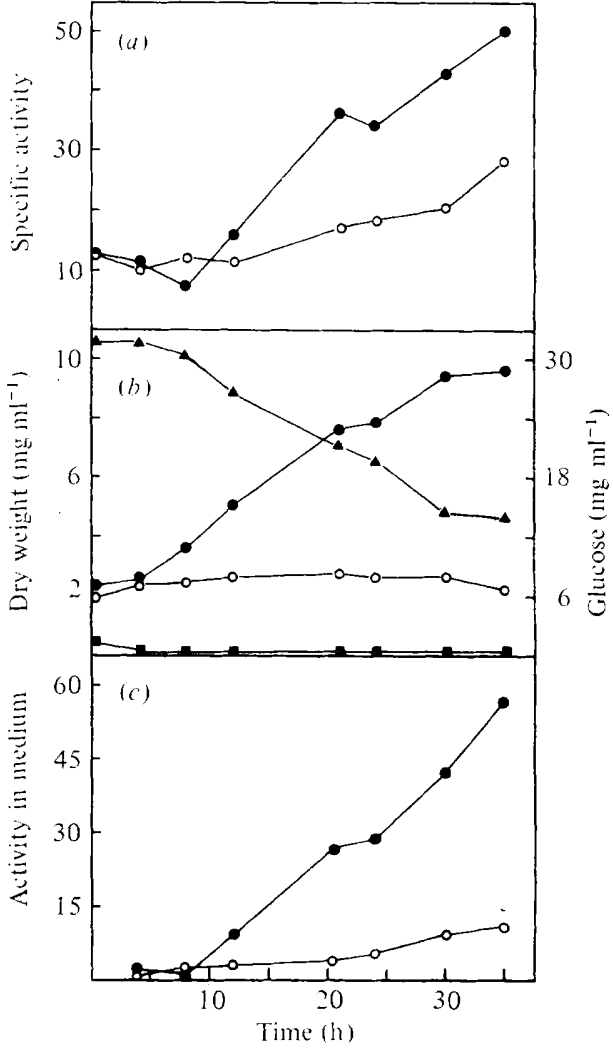

Fig. 4

Fig. 3. Production of 1,3- $\beta$-glucanase and 1,6- $\beta$-glucanase by Trichoderma viride grown in modified Czapek medium. (a) Specific activity [units (mg protein) ${ }^{-1}$ ] of $1,3-\beta$-glucanase $(O)$ and $1,6-\beta$ glucanase $(\bigcirc)$ in cell-free extracts. $(b)$ Dry weight of cells $(\bigcirc)$ and glucose concentration $(\boldsymbol{\Delta})$. (c) Activity in culture medium (units $\mathrm{ml}^{-1}$ ) of $1,3-\beta$-glucanase $(0)$ and $1,6-\beta$-glucanase $(\bigcirc)$.

Fig. 4. Effect of glucose on the production of 1,3- $\beta$-glucanase by Trichoderma viride grown in modified Czapek medium. Actively growing cells were transferred to media containing glucose at $5 \mathrm{~mm}(\bigcirc)$ or $170 \mathrm{~mm}(\bigcirc)$, as described in Methods. (a) Specific activity [units (mg protein) ${ }^{-1}$ ] in cell-free extracts. $(b)$ Glucose concentration $(\boldsymbol{\Delta})$ and dry weight of cells $(\boldsymbol{O})$ in the high-glucose medium, and glucose concentration $(\boldsymbol{a})$ and dry weight of cells $(\bigcirc)$ in the low-glucose medium. (c) Enzyme activity in culture medium (units $\mathrm{ml}^{-1}$ ).

grown in buffered minimal medium (Fig. 6) so that the $\mathrm{pH}$ of the culture remained between 6 and 7 . Under these conditions the production of $1,3-\beta$-glucanase showed a pattern similar to that observed in $T$. viride. Growth was accompanied by an increase in the specific activity of 1,3- $\beta$-glucanase which ceased when the culture entered stationary phase. Again when actively growing cells were transferred to high- or low-glucose medium (Fig. 7), synthesis of 1,3- $\beta$-glucanase either continued or was immediately halted, respectively. Activities of $1,6-\beta$-glucanase were much lower but they showed a similar pattern of variation to that of $1,3-\beta$-glucanase.

\section{DISCUSSION}

Evidence is presented for two different modes of synthesis of $1,3-\beta$-glucanase in fungal species. Glucose represses the synthesis of $\beta$-glucanases in $N$. crassa; production of these enzymes during active growth in the presence of glucose is almost negligible but in conditions of carbon source starvation derepression takes place and the enzymes are produced in 


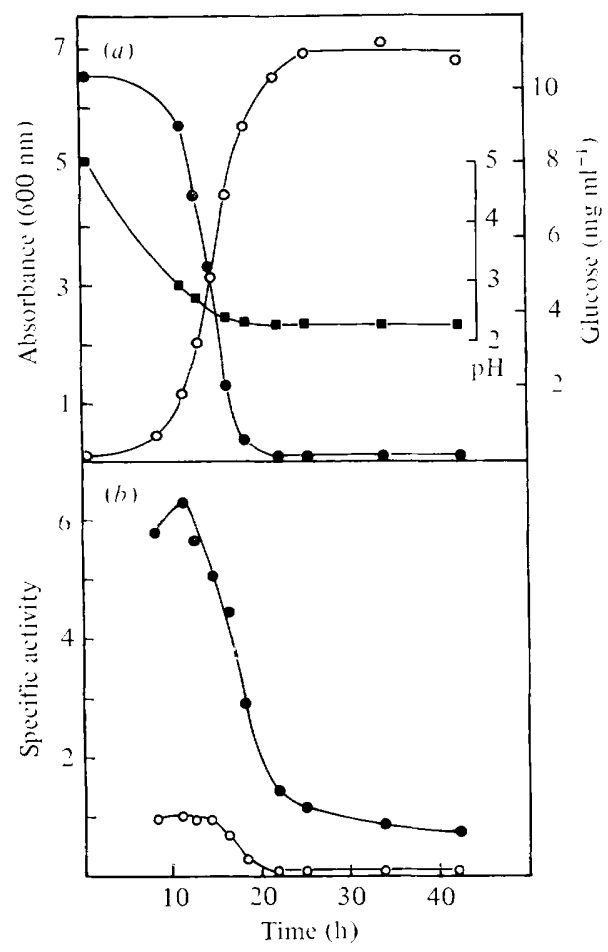

Fig. 5

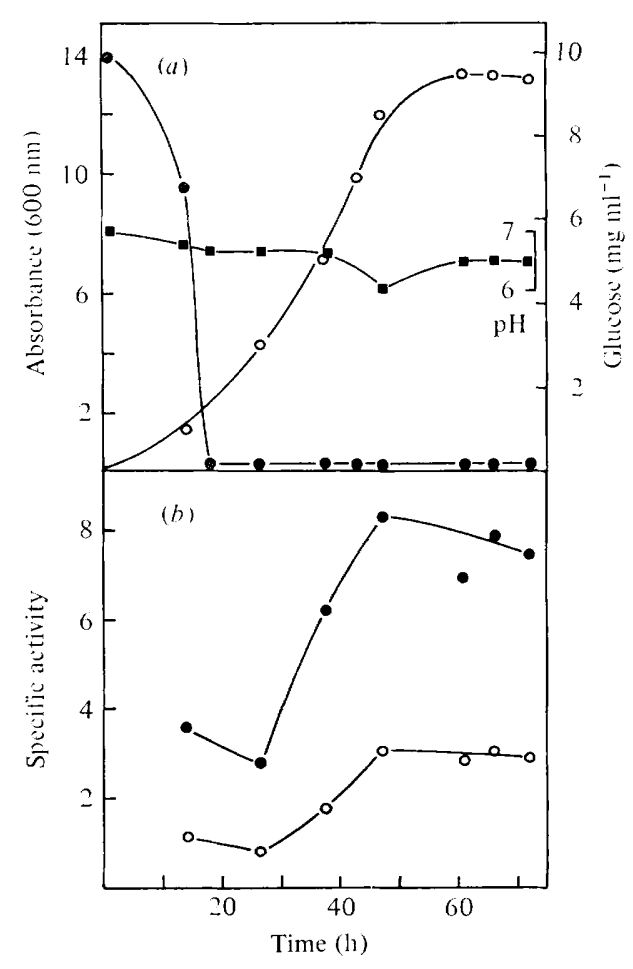

Fig. 6

Fig. 5. Production of 1,3- $\beta$-glucanase and 1,6- $\beta$-glucanase by Saccharomyces cerevisiae grown in unbuffered minimal medium. (a) Absorbance at $600 \mathrm{~nm}(\bigcirc)$, glucose concentration (O) and pH (D). (b) Specific activity [units (mg protein) ${ }^{-1}$ ] of $1,3-\beta$-glucanase $(O)$ and $1,6-\beta$-glucanase $(O)$ in cell-free extracts.

Fig. 6. Production of 1,3- $\beta$-glucanase and 1,6- $\beta$-glucanase by Saccharomyces cerevisiae grown in buffered minimal medium. Symbols as in Fig. 5 .

significant amounts. This kind of control is also exerted on other fungal 1,3- $\beta$-glucanases such as those of $P$. italicum (Santos et al., 1977), the Basidiomycete QM806 (Friebe \& Holldorf, 1975) and on bacterial $\beta$-glucanases (Lilley \& Bull, 1974) and certain other fungal carbohydrases (Hulme \& Stranks, 1971).

In contrast, the production of $\beta$-glucanases by $T$. viride and $S$. cerevisiae is not repressed by glucose. In these species, the enzymes are actively produced during growth in the presence of glucose so that the specific activity increases continuously, and resting cells in lowglucose medium either fail to produce the enzyme or produce it in significantly smaller quantities. Other enzymes which are actively produced during exponential growth with increasing specific activity are endo- $\beta$-glucanase of Schizosaccharomyces pombe (Barras, 1972 ) and alkaline phosphatase of $S$. cerevisiae when grown in a low-phosphate medium (Toh-e et al., 1976). The fact that 1,6- $\beta$-glucanase of $S$. cerevisiae shows a similar pattern of variation to that of $1,3-\beta$-glucanase is not surprising as it is known that in $S$. cerevisiae $1,6-\beta$-glucanase activity is only due to one of the $1,3-\beta$-glucanases which is also capable of degrading 1,6- $\beta$-linkages although with a much lower efficiency (Farkas et al., 1973). A note of caution should be made with regard to the inactivation of $\beta$-glucanases of $S$. cerevisiae by low $\mathrm{pH}$ in unbuffered medium after a few hours of growth (Figs 5 and 6). Unless a buffered medium is used, any data regarding the level of these enzymes could be completely meaningless.

Although the exact roles of $1,3-\beta$-glucanases and 1,6- $\beta$-glucanases in fungi remain to be established, one might speculate that the patterns of synthesis could be meaningful with 


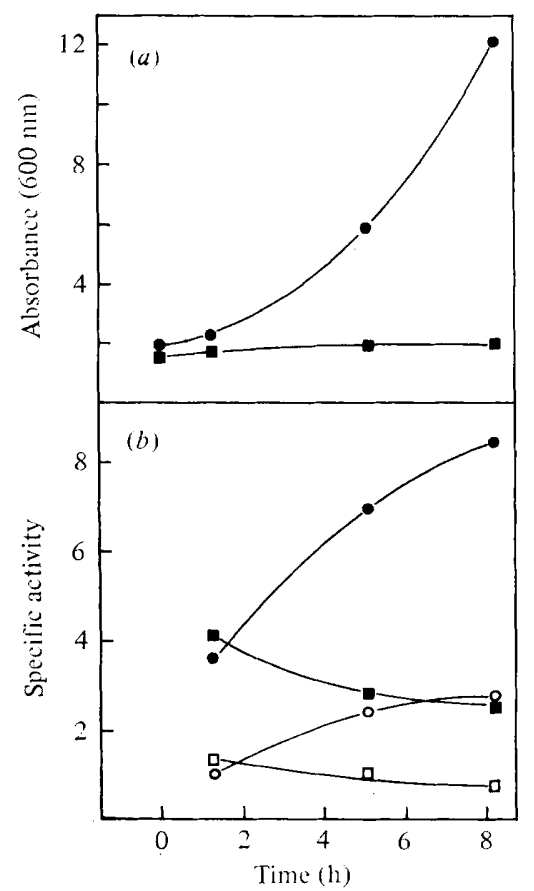

Fig. 7. Effect of glucose on the production of $\beta$-glucanases by Saccharomyces cerevisiae. Actively growing cells were transferred to media containing glucose at $5 \mathrm{~mm}(\boldsymbol{\square}, \square)$ or $170 \mathrm{~mm}(\boldsymbol{O}, \bigcirc)$. (a) Absorbance at $600 \mathrm{~nm}$. (b) Specific activity [units (mg protein) ${ }^{-1}$ ] of 1,3 - $\beta$-glucanase $(\boldsymbol{O}, \mathbf{0})$ and $1,6-\beta$-glucanase $(\bigcirc, \square)$ in cell-free extracts.

regard to the possible functions of the enzymes. It has been postulated that growth and extension of the fungal wall could be the result of a balance between lysis and synthesis. A controlled hydrolysis of the wall components at certain points could lead to the appearance of zones where the synthesizing system acts by adding new components resulting in the growth of the wall (Bartnicki-García, 1973). According to this hypothesis, $\beta$-glucanases could be lytic enzymes involved in the process of wall formation and the fact that they increase in specific activity during exponential growth of $T$. viride and $S$. cerevisiae is consistent with this idea. Alternatively the production of $\beta$-glucanases by resting cells of $N$. crassa could be directly linked to metabolism, such as the mobilization of wall or external glucan, or to some morphogenetic change such as conidiation. The diversity of fungal glucanases extends not only to their properties and mode of substrate attack but to differences in their regulation when grown in similar media.

We wish to thank Mr Tomás Santos for many helpful discussions and Mr N. Skinner for correcting the manuscript. This investigation was aided by a grant from Comision Asesora de Investigación Científica. F. del Rey is the recipient of a fellowship from Ministerio de Educación y Ciencia (Programa de Formación del Personal Investigador).

\section{REFERENCES}

BARRAS, D. R. (1972). A $\beta$-glucan-endohydrolase from Schizosaccharomyces pombe. Antonie van Leeuwenhoek 38, 65-80.

BARTNICKI-GARCía, S. (1973). Fundamental aspects of hyphal morphogenesis. Symposia of the Society for General Microbiology 23, 245-267.
Cortat, M., Matile, P. \& Wiemken, A. (1972). Isolation of glucanase-containing vesicles from budding yeast. Archiv für Mikrobiologie 82, 189205.

Farkas, V., Biely, P. \& Bauer, S. (1973). Extracellular $\beta$-glucanases of the yeast Saccharomyces 
cerevisiae. Biochimica et biophysica acta 321, 246-255.

Friebe, B. \& Holldorf, A. W. (1975). Control of extracellular $\beta$-1,3-glucanase activity in a basidiomycete species. Journal of Bacteriology 122, 818825.

García-Acha, I. \& Villanueva, J. R. (1963). The use of Streptomyces enzyme in the preparation of protoplasts from mold spores. Canadian Journal of Microbiology 9, 139-140.

Hulme, H. A. \& Stranks, D. W. (1971). Regulation of cellulase production by Myrothecium verrucaria grown on non-cellulosic substrates. Journal of General Microbiology 69, 145-155.

Lilley, G. \& Bull, A. T. (1974). The production of $\beta$-1,3-glucanase by a thermophilic species of Streptomyces. Journal of General Microbiology 83, 123-133.

LindBerG, B. \& McPherson, J. (1954). Studies on the chemistry of lichens. VI. The structure of pustulan. Acta chemica scandinavica 8, 985-988.

Lowry, O. H., Rosebrough, N. J., FARr, A. L. \& RANDALL, R. J. (1951). Protein measurement with the Folin phenol reagent. Journal of Biological Chemistry 193, 265-275.

Santos, T., Villanueva, J. R. \& Nombela, C. (1977). Production and catabolite repression of Penicillium italicum $\beta$-glucanases. Journul of Bacteriology 129, 52-58.

Santos, T., Sánchez, M., Villanueva, J. R. \& Nombela, C. (1978a). Regulation of the $\beta-1,3-$ glucanase system in $P$. italicum: glucose repression of the various enzymes. Journal of Bacteriology 133, 465-472.

Santos, T., Villanueva, J. R. \& Nombela, C. (1978b). Regulation of $\beta$-1,3-glucanase synthesis in Penicillium italicum. Journal of Bacteriology 133, 542-549.

ToH-E, A., Nakamura, H. \& Oshima, Y. (1976). A gene controlling the synthesis of non-specific alkaline phosphatase in Saccharomyces cerevisiae. Biochimica et biophysica acta 428, 182-192.

VoGEL, H. J. (1956). A convenient growth medium for Neurospora (medium N). Microbial Genetics Bulletin 13, 42-43. 